\title{
The Monetary Approch to Balance of Payments and Exchange Rate Equilibrium Determination with an Empirical Application to the Case of Algeria
}

\author{
Lakhdar Adouka ${ }^{1}$, Yahia Boucheta ${ }^{2}$, Abderahmmane Chenini ${ }^{1}$, Abdennour Belmimoune ${ }^{1} \&$ Mohamed \\ Kerbouche $^{1}$ \\ ${ }^{1}$ Faculty of Economics, Commercial Sciences and Management Sciences, University of Mascara, University of \\ Mascara, Algeria \\ ${ }^{2}$ Faculty of Economics, Commercial Sciences and Management Sciences, University of Sidi BelAbbes, Algeria \\ Correspondence: Lakhdar Adouka, Commercial Sciences and Management Sciences, University of Mascara, \\ University of Mascara, Algeria. E-mail: ladouka@gmail.com
}

$\begin{array}{ll}\text { Received: August 5, } 2012 & \text { Accepted: January 14, } 2013 \quad \text { Online Published: March 11, } 2013 \\ \text { doi:10.5539/ibr.v6n4p114 } & \text { URL: http://dx.doi.org/10.5539/ibr.v6n4p114 }\end{array}$

\begin{abstract}
The aim of this paper is to explain the exchange rate by using the fundamental determinants of cointegration techniques to search if there is a long-term relationship between exchange rate and fundamentals of the Algerian economy. For this purpose we applied the model of the monetary approach of the balance of payments to the Algerian economy. We based in this study in Edward model That's takes into account all external factors (terms of trade, external debt ...) and internal factors (government expenditure, budget deficit, money supply ...) for the determination of real exchange rate equilibrium, and we takes in consideration two variables, domestic credit, and international reserve, as they are the most important in monetary approach to balance of payments. The results of our study are summarized in the following point: The variable international reserve has a positive sign (the expected sign is positive) that allowed us to conclude that an increase in international reserve unit will result in an appreciation of the exchange rate of $9.60 * 10^{-12} \%$. The domestic credit has a positive influence on real exchange rate (the expected sign is negative), that allowed us to conclude that an increase in domestic credit unit will result in an appreciation of the exchange rate of $9.41 * 10^{-10} \%$. This result contradicts in the economy theory.
\end{abstract}

Keywords: NER, REER, stationarity, co-integration, ECM

\section{Introduction}

The observed high volatility of real exchange rates raises on a recurrent basis the problem of determining a reference level or equilibrium level. In addition, the effectiveness of the exchange rate as an instrument of the economic policy depends on a strong knowledge of its equilibrium level. Indeed, in the absence of such reference, the concepts of under or overvaluation of a currency relative to another would no longer make sense. It is therefore important to focus on the determination of an equilibrium real exchange rate. This is a major problem in international macroeconomic for the exchange rate is one of the adjustment tools of a country monetary trade policy. Thus, the knowledge of the equilibrium level represents a considerable challenge.

The objective of this paper is to explain the exchange rate by the fundamental determinants by using cointegration techniques to find if there is a long-term relationship between the exchange rate and the fundamental elements of the Algerian economy.

We propose in this paper to apply the model of the monetary approach of the Algerian economy balance of payments. We chose this model because it takes all the external factors (terms of trade, external debt ...) and internal factors (government expenditure, budget deficit, money supply ...) into account in determining the exchange rate. To this end, this model determines the exchange rate as a rate that ensures simultaneously internal and external balance (Edwards, 1989)For the empirical application of this model, we use the error correction model (ECM) (Dornbusch) while ensuring that:

1- The series are nonstationary I (1) $\Rightarrow>$ stationarity tests (Dickey D \& Fuller, 1981).

2- The variables are cointegrated (long term stationarity relationship) which allows us to estimate an ECM model 
describing the dynamics of return to equilibrium.

This article is build following these steps: model presentation, statistical data analysis, study of the stationarity and estimate ECM model.

\section{The Theoretical Background of the Monetary Approach to the Balance of Payments}

Referring to the study of Jean-Jacques Ekomie, the monetary approach to the balance of payments (Bourguinat, 1997; Greffe, 1991; Hellier, 1994; Neme, 1991) is one of the main theories of the adjustment of international payments. This approach is considered as an extension of Hume's (1752) automatic foreign trade equilibrium, Thornton (1802), Ricardo (1810, 1817) and Stuart Mull (1848).

The monetary approach to the balance of payments was developed by the International Monetary Fund (Polak, 1957) and was further developed by Mundell (1968, 1971), Dornbush (1973), Mussa (1974), Johnson (1975, 1976, 1977) and Frenkel and Johnson (1976).

The approach to the balance of payments (Ekomil, 2000) is essentially a monetary phenomenon. Its overall balance is a mere reflection of the domestic currency market situation. Therefore, the variations in international reserves, used in accessing the payments imbalances depend on the gap between supply and demand for money. An expansive monetary policy thus leads to an excess of overall expenditure source of foreign exchange reserves decline. This leads to the national currency depreciation to readjust the deficits of balance of payments (EkomiI, 2000). The monetary approach to balance of payments establishes a fundamental relationship between the exchange rate evolution and the evolution of the internal and external money mass from the following equations (Hellier, 1994).

$$
\begin{gathered}
s=\frac{p}{p^{*}} \\
M_{d}=K P Y \\
M_{d}^{*}=K^{*} P^{*} Y^{*} \\
M_{O}=m(c+s R) \\
M_{d}=M_{O}=M \\
M_{d}^{*}=M_{O}^{*}=M^{*}
\end{gathered}
$$

With:

$P$ : The domestic price level;

$P^{*}$ : The foreign price level;

$S$ : The expected exchange rate;

$M_{d}$ : Demand for the money;

$M_{O}$ : The money supply;

$m:$ The reciprocal of reserve ratio;

$c:$ The volume of credit;

$R$ : The stock of foreign currencies reserve;

Equation (1) describes the principle of purchasing power parity (Balassa, 1964) according to which a national currency unit must have the same purchasing power in the domestic economy and abroad given the exchange rate that exists between countries. Function (2) represents a money demand function defined by Fisher's quantitative law of currency in which $\mathrm{Md}$ depends on real income $\mathrm{Y}$ and the general level of prices $\mathrm{P}$. Equation (3) describes the equilibrium condition of the money market; the money supply Mo has an internalcomponent; the domestic credit and an external component which is the country's reserve currency. The equilibrium condition of the money market allows us to write the following relation (Mohamed, 2003)

$$
M_{d}=m(c+s R)
$$

By replacing Md by its value, we obtain: 


$$
M_{d}=K P Y=m(c+s R)
$$

With the hypothesis of the price unicity law, one can write the following relation:

$$
K S P^{*} Y=m(c+s R)
$$

From equation (6) we deduce the following relationship:

$$
\frac{K S P^{*} Y}{m}-c=s R
$$

From this, we can say that the external equilibrium depends on the level of domestic credit. Any excess of the money supply relative to demand automatically leads to a payments balance deficit. We will discuss two situations (Mohamed, 2003).

If $\mathrm{Md} \leq \mathrm{Ms}$, The balance of payments is in deficit, the devaluation allows to increase the prices.

The price effect reduces monetary inflows and increases the demand for money. -If Md $\geq$ Ms, An increase of money supply through credit helps restore the equilibrium. In deriving the above equations we have (EkomiI, 2000)

$$
\begin{gathered}
\frac{d s}{s}=i-i^{*} \\
\frac{d M_{d}}{M_{d}}=i \quad \frac{d M_{d}^{*}}{M_{d}^{*}}=i^{*} \\
\frac{d M_{d}}{M_{d}}=\frac{d M_{O}}{M_{O}}=\frac{d M}{M}=i \\
\frac{d M_{d}^{*}}{M_{d}^{*}}=\frac{d M_{O}^{*}}{M_{O}^{*}}=\frac{d M^{*}}{M^{*}}=i^{*}
\end{gathered}
$$

With $\mathrm{i}$ and $\mathrm{i}^{*}$ respectively representing the domestic inflation rate and foreign one.

Building on equations (8) and (9), equation (7) becomes:

$$
\frac{d s}{s}=\frac{d M}{M}-\frac{d M^{*}}{M^{*}}
$$

According to this formula, we can say that according to the monetary approach to balance of payment, any change in the exchange rate corresponds to a difference of the variation rates of the internal and external component of the money supply. This means that, in a rating system with uncertainty, an increase of the stock of domestic currency stronger than that of the foreign currency is likely to cause the depreciation of the national currency for production levels and data. In contrast, an expansion of the foreign currency faster than the domestic money supply leads to the appreciation of the currency.

The monetary model of balance of payments can be written as follows (EkomiI, 2000) (Greffe, 1991).

$$
\log \left(T C R_{t}\right)=a \log \left(C I_{t}\right)+b \log \left(R E_{t}\right)+c
$$

With:

$T C R$ : The real exchange rate

$C I$ : The Domestic Credit

$R E:$ International reserves (foreign assets)

$c:$ Constant

It is found that the model of balance of payments can be written as a function of domestic credit and international reserves (foreign assets).

\subsection{The Domestic Credit}

Domestic credit includes net claims on the state and credits to the economy. Net claims on the state or claims on the public tresor can identify the monetary stance of the state vis-à-vis the monetary system (EkomiI, 2000). In 
contrast, credits to the economy represent the outstanding loans from the monetary system to public enterprises, non-monetary financial institutions and the private sector that receives the bulk of these funds (EkomiI, 2000).

To measure the impact of domestic credit on net foreign assets, it makes sense to use Polak's coefficient (Mundell R.A, 1960) (Mussa, 1974) which is calculated by the following formula:

$$
P=\frac{H \cdot V}{1+H \cdot V}
$$

With:

P: Polak coefficient;

$\mathrm{H}$ : The degree of openness;

$\mathrm{V}$ : The speed of money circulation.

Polak's coefficient estimate the loss of foreign currency induced by the expansion of domestic credit.

A high level of openness can be explained by the production apparatus inability to satisfy the basic needs of the country. Therefore, an expansive credit policy leads to an increase in imports and leaves a great pressure on foreign assets.

There is an inverse relationship between the exchange rate and domestic credits that is to say an increase in domestic credits leads to a depreciation of the real exchange rate, while falling domestic credit appreciates the real exchange rate.

\subsection{The Net Foreign Assets}

Net foreign assets represent the difference between foreign currency assets of the primary banks and the central bank, consisting mainly of assets deposited in the operating account within the Treasury, on one hand, and one the other hand the short-term liabilities of these same institutions (EkomiI, 2000). They allows to appreciate the external covering of a country currency. There is a direct relationship between the exchange rate and external assets that is to say an increase in foreign assets leads to an appreciation of real exchange rate, while lower foreign assets depreciate the real exchange rate.

\section{Empirical Application of the Model of the Monetary Approach to the Payments Balance}

\subsection{Model Specification}

The estimated model has two relationships linking the real exchange rate of the dinar and its fundamental determinants; a stationary long term relationship and a short term relationship taking into account the dynamics of convergence to the equilibrium point. So we have:

$$
\log \mathrm{Q}_{\mathrm{t}}=\beta^{\prime} \log X_{t}+U_{t}
$$

With $\mathrm{X}$ takes the following variables:

\section{CI: The Domestic Credit;}

RE: The international reserves;

Ut: An independently and identically distributed random walk (iid).

The real exchange rate $(\mathrm{Q})$ is defined as follows:

$$
Q=\frac{T C N}{P P A}
$$

With:

TCN: nominal exchange rate;

PPP: the purchasing power parity.

The reduced model of the monetary approach to balance of payments that we will apply is written in this form:

$$
Q=a(C R I N T)+b(R E S I N T)+c
$$

The equilibrium real exchange rate $\mathrm{Q}^{*}$ is derived by replacing in equation (12) or equation (13) the fundamental determinants by their expected values Xs.

The error correction models (ECM), allow to model the adjustments that lead to a situation of long-term 
equilibrium. These are dynamic models that incorporate both changes in short-term and long term. The ECM allows the integration of short-term fluctuations around the long-term equilibrium (Johnson, 1977).

The error correction model (ECM) is written as follows:

$$
\Delta \mathrm{Q}_{\mathrm{t}}=\gamma\left(\mathrm{Q}_{\mathrm{t}-1}-\beta^{\prime} \mathrm{X}_{\mathrm{t}-1}\right)+\sum_{\mathrm{i}=1}^{\mathrm{p}} \lambda_{\mathrm{i}} \Delta \mathrm{X}_{\mathrm{t}-\mathrm{i}}+\sum_{j=0}^{p} \rho_{\mathrm{j}} \Delta \mathrm{Q}_{\mathrm{t}-\mathrm{j}}+\mathrm{w}_{\mathrm{t}}
$$

With

$\Delta$ the difference operator; wt an independent and identically distributed random walk;

For the equilibrium to be stable in the long-term $\gamma$ must be in the open interval from -2 to 0 (Baffes, Elbadawi, \& O'connel, 1999).

In order to determine a referential real exchange rate for the Algerian economy we will apply empirically the model of the monetary approach to balance of payments using the following static equation:

$$
Q=a(C R I N T)+b(R E S I N T)+c
$$

\subsection{Algerian Exchange Policy and Statistical Data}

\subsubsection{Algerian Exchange Policy}

Exchange policy has objective as how to determinate exchange rate of national currency. The exchange rate is the price at which one currency can be exchanged against another. The monetary value of the most common is the bilateral exchange rate quoted by a market operator or exchange published by a newspaper. The bilateral exchange rate of the dinar / dollar was fixed at 4.94 in 1974 was jump up in 2000 to 83.

Assessing the value of a currency on the foreign exchange market by studying one or more bilateral exchange rates, can be deceiver in the same way that estimating the general price level considering only the price of one or several baskets product. As any price index, the bilateral exchange rate of a currency can be combined in various ways to construct an index of effective exchange rate. Policies establishing the exchange regulations of the national currency have known four main phases:

\subsubsection{From 1961 to 1970}

After independence, Algeria was attached to the France. The currency was freely convertible and transferable. Unfortunately, after the massive capital flight and imbalances in the balance of payments, monetary authority instituted in 1963, the exchange control on all transactions with the rest of the world.

This change has been accompanied by various measures to control foreign trade, for example: the quota of foreign trade, the creation of the National Board of Trade, the control of all operations of export and import.

These measures were followed in April 1964 by the establishment of the national monetary unit "Algerian dinar" whose value was set at $180 \mathrm{mg}$ of fine gold. The Algerian dinar (DA) has replaced the new franc (NF) for parity $1 \mathrm{DA}=1 \mathrm{NF}$.

For political reasons, Algeria has decided to attach the value of its currency to a basket of currencies selected according to its important trading partners. The value of the dinar is administratively determined based on changes in the basket of currencies. The price of each currency is assigned by weighting coefficient giving the importance of external trade expressed in the same currency.

The attachment of the dinar to a basket of currencies, offers the advantage of stabilizing the nominal effective exchange rate, but leaves a variability bilateral price against the currencies in the basket this will increase the risk of changes to decision maker.

\subsubsection{From 1978 to 1988}

This stage is characterized by the implementation of a new management system for public companies, including the Socialist Management of Enterprises (GSE), the General Statute Worker (TMS) and the launch of economic development plans. The aim is to stimulate productive investment and facilitate foreign trade operations. Many legal texts came to regulate investment.

This period is marked by the total monopoly of the state on the economy. All production operations and marketing offices are confided to the state. Legal texts have set the terms of access to foreign exchange market.

All imports registered under the monopoly are subject to GIA (Global Import Authorization) and any product is not in this context requires an import license. 
The public and private enterprises cannot benefit from the retrocession of the foreign currency generated by their activities with the rest of the world, With the exception of the mixed-economy companies, the amount of retrocession is fixed at $20 \%$.

As well as from 1974 the access restrictions to the foreign exchange market accompanied by policies of import quotas had given birth to the parallel exchange market (parallel market, informal market or black market of exchange rates).

The table 1 shows the evolution of the Algerian dinar in the market of official and unofficial exchange.

Table 1. Evolution of the Algerian dinar in the market of official and unofficial exchange

\begin{tabular}{llllll}
\hline & 1970 & 1974 & 1977 & 1980 & 1987 \\
\hline Official Market & 1.0 & 1.0 & 1.3 & 0.62 & 0.80 \\
Unofficial Market & 1.0 & 1.1 & 1.5 & 2.0 & 4.0 \\
\hline
\end{tabular}

Source: A, Henni, Essai sur l'économie parallèle. Ed. Enag 1991.

\subsubsection{From 1988 to 1994}

The events that have shaken the Algeria in 1988 have given birth to a beginning of a break with the socialist mode of management. As well new reforms to economic and legal character came give a new breath to the Algerian economy, among as: the law on the autonomy of enterprises (1988), the law on currency and credit (1990), the law on the price.

The objective of these new reforms was to break with the monopoly of the State on foreign trade, to rehabilitate the private companies, to gradually provide a management autonomy to public enterprises for their permit to operate a good transition to a market economy, finally to ensure the autonomy of the Central Bank in relation to the Public Treasury.

The reforms recommend: that private firms can access the official exchange market through the chamber of commerce, 1991 the launch of a partial convertibility (current account), the realization of full convertibility in 1993

\subsubsection{From 1994 till Now}

Access to the official market of exchange is made possible by the IMF to all economic operators (public or private) following the signature by the Algeria in 1994 of a first agreement on the rescheduling of a portion of its debt. The exchange rate regime of this period is a system of managed floating. The exchange rate varies according to supply and demand of the market for interbank exchange.

In other words, it is freely determined according to the law of supply and demand for foreign currency on the interbank foreign exchange market which has been established by a regulation of the Bank of Algeria in December 1995.On the legal plan this market is defined as: "the place where the banks and financial institutions negotiate freely of operations for the purchase or sale of currency against the national currency, for their account or for their client."

The determination of exchange rates of dinars is based on the offer and the demand for foreign exchange, of this, stems two questions:

1- From where comes the supply of foreign currency on the interbank market?

2- What is the demand for currency on the interbank market?

The supply of foreign currency on the interbank foreign exchange market comes from:

1- of the interventions of the Bank of Algeria, during the operations for the purchase of national currency;

2- on the part of export earnings non-hydrocarbon, that any exporter resident in Algeria is required to surrender against the national currency;

3- of the financial credits or borrowing in currency, contracted by the banks and financial institutions for their account or for their customers.

The demand for foreign currency on the interbank market is used to cover the common operations of banks and financial institutions as well as those of their customers. These operations are limited to funding operations that require the non-hydrocarbon, to the coverage of imports and the payment for the service of external debt. The market for interbank exchange of the dinar consists of two compartments: the first is the foreign exchange 
transactions in cash and the second the foreign exchange transactions in the long term.

Nowadays, the market for interbank exchange of dinar remains incomplete. Although the market for foreign exchange transactions had been planned in the regulation of the Bank of Algeria in 1995, but the market still unfindable. Thus, in this market, there are no derivative products. This shows well the under development of the Algerian banking system.

We can summarize the mission of the Bank of Algeria in the following points.

1- "It must monitor the operation of the interbank market".

2- "It must ensure the regulatory compliance of operations for the purchase and sale of foreign currency".

3- "It must continuously ensure compliance with the prudential ratios of the various banks that occur on the foreign exchange market".

Concerning the operation of the market for interbank exchange, currently interbank exchange is supposed to operate continuously, in other words, the exchange rate for the dinar can vary instantly. Contrariwise before restoration of interbank exchange market, the exchange rate for the dinar was determined, following the fixing for a period of one week. However, the Bank of Algeria can intervene in the revenue of hydrocarbon levels to avoid the exchange-rate undesirable. The convertibility of the dinar is regulated and limited to only operations of the current account and to the payment of expenses of health and education, when these two operations are carried out abroad.

\subsubsection{The Statistical Data}

Data taken from the International Financial Statistics (IFS) are annual and cover the period 1980-2010.
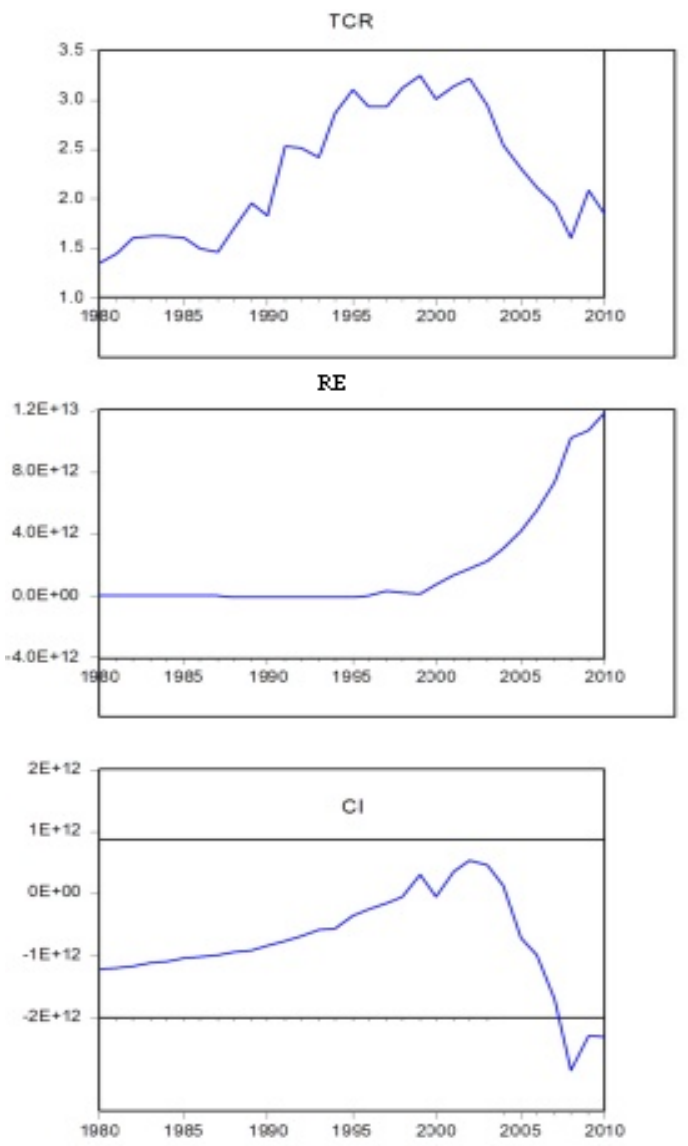

Figure 1. The evolution of the variables of interest

We can notice on the figure of domestic credit a slow credit growth during the period 1970-1980. During the following period from 1980 to 1990 the credit growth accelerated more than in the previous period. This acceleration in the growth can be justified by costs of the developing program with rising costs from one year to the 
next. There is also a decrease of the domestic credit curve during the period from 1990 to 2000 . This period was characterized by several devaluations of the national currency the Dinar. There was devaluation in 1991, 1994 and 1996. This period knew the application of the structural adjustment program during the period 1994-1998. There is growth of the credit curve from 2000 to 2005, period which corresponds to the application of the economic stimulus program.

On the curve of international reserves, we can detect two periods, the curve is constant from 1980 to 2000 and then it grows starting from the year 2000. Algeria being an oil exporting country whose oil revenue accounts for almost $98 \%$ of its total revenue, makes that foreign assets (international reserves) are strongly bound to the price of oil, which has seen a significant increase since the year 2000 .

\subsection{Testing of Unit Root}

There are many unit root tests. The pioneering work in this area are those of Fuller (1976) and Dickey and Fuller (1979.1980). The Dickey-Fuller tests are parametric, this tests highlight the character of a stationary or non-chronic with determining a deterministic trend or stochastic. These tests are based on an estimate of an autoregressive process.

Dickey and Fuller consider three basic models for the series:

- Model (1) model without constant or deterministic trend

$$
X_{t}=\rho X_{t-1}+\varepsilon_{t}
$$

- Model (2): model with constant and non-trend

$$
X_{t}=\rho X_{t-1}+b+\varepsilon_{t}
$$

- Model (3): model with constant and trend

$$
\mathrm{X}_{\mathrm{t}}=\rho \mathrm{X}_{\mathrm{t}-1}+\mathrm{at}+\mathrm{b}+\varepsilon_{\mathrm{t}}
$$

In all three models, we assume that $\varepsilon_{\mathrm{t}} \longrightarrow \mathrm{BB}\left(0, \sigma_{\varepsilon}^{2}\right)$

The test principle is:

$\mathrm{H}_{0}: \rho=1$ Presence of a unit root; the series is non-stationary;

$\mathrm{H}_{0}:|\rho|<1$ Absence of unit root; the series is stationary;

If $\mathrm{H}_{0}: \rho=1$ is accepted in one of these three models, then the process is non stationary.

The test strategy is sequential; we start from the model (3) to the model (1).

In our study we will apply the ADF test and we determined the number of lags using partil autocorrelation function by studying the significance of the coefficients of partial correlations. The application of this method based on the study of corréllogramme for different variables in equation (12), we obtained the lags for all variables.

After we determined the lags for each variable, we adopted the strategy of sequential ADF test to examine the stationarity of the study variables. The following table summarizes our application:

Table 2. Augmented Dickey-Fuller test

\begin{tabular}{llll}
\hline Variables & Lag & ADF & Order of integration \\
\hline$Q$ & 1 & $-0,12$ & $\mathrm{I}(1)$ \\
$d Q$ & 1 & $-5,41$ & $\mathrm{I}(0)$ \\
$C R I N T$ & 1 & $-0,72$ & $\mathrm{I}(1)$ \\
RESINT & 1 & 6,82 & $\mathrm{I}(1)$ \\
$d($ RESINT $)$ & 1 & $-1,65^{*}$ & $\mathrm{I}(0)$ \\
$d($ CRINT $)$ & 1 & $-4,35$ & $\mathrm{I}(0)$ \\
\hline
\end{tabular}

By comparing the ADF statistic (Table 2) with the critical value of ADF for a significance level of 5\%. This comparison shows that the null hypothesis of nonstationarity is accepted for the variables in level (real exchange rate, domestic credit, international reserve), by cons we see that the hypothesis null is rejected for the same variables in first differences (Table 2) the Series (real exchange rate, domestic credit, international reserve) are 
then integrated of order 1 , since the first difference of each of these variables is stationary I ( 0$)$.

\subsection{The Cointegration Test}

We recall, for a long term relationship between several variables, two conditions must be met, first the variables must be non-stationary and integrated into the same order. Secondly their stochastic trends must be linked.

The ADF tests suggest therefore assume the existence, of a cointegration relation between real exchange rate, domestic credit, international reserve.

To investigate the existence of a long-term relationship between the variables in the model, we applied two methods:

- the general method of maximum likelihood (Johnson, 1977) (Johnson, 1975) (Johnson \& Frenkel, 1976).

- The two-step method of Engle and Granger (1978).

\subsubsection{The Johansen Test}

The applied of the trace test, we can detect the number of cointegration vectors. The hypothesis of this test is:

- $\mathrm{H}_{0}$ : There are at most $\mathrm{r}$ cointegrations vectors.

- $\mathrm{H}_{1}$ : There are at least $\mathrm{r}$ cointégations vectors.

When the statistical Trace is below the critical values at a significance level, we accept $\mathrm{H}_{0}$; otherwise we reject $\mathrm{H}_{0}$. This test is applied sequentially from $\mathrm{r}=0$ to $\mathrm{r}=\mathrm{k}-1$.

Table 3. The Johansen test

\begin{tabular}{llll}
\hline Eigen values & Likelihood ratio (trace statistic) & critical value & Hypothesis on the number the of EC \\
\hline 0,37 & 33,62 & 29,79 & None \\
0,24 & 9,08 & 15,49 & At least one \\
0,007 & 0,22 & 3,84 & At least two \\
\hline
\end{tabular}

First we test the hypothesis that the number of cointegration vectors is strictly zero $(r=0)$ (column Likelhood ratio, Table 3).

We note that the statistics of the Trace for $r=0$ (33.6) is greater than the critical value (29.79), which leads us to reject $\mathrm{H}_{0}$.

We then test the hypothesis that the number of cointegration vectors is strictly equal to one $(r=1)$. Statistics of Trace for $r=1$ (9.08) is lower than the critical value (15.49), which brings us therefore to accept $\mathrm{H}_{0}$.

With The tests trace of the Johansen, we conclude that there is a cointegration relationship between the three variables.

\subsubsection{Application Method of Engle and Granger}

The notion of cointegration assumes that if two variables $\mathrm{X}$ and $\mathrm{Y}$ are integrated of order one (I (1)), and there exist a stationary linear combination of these variables I ( 0 ), then one can conclude that $\mathrm{X}$ and $\mathrm{Y}$ are cointegrated of order $(1,1)$. We have already shown that the series are nonstationary and integrated of the same order. It remains, then, to test if the residual of this linear combination is stationary. In the case where, the deviations from the equilibrium value tend to cancel in time then, a long-term relationship exist between the variables.

We estimate in a first stage, with OLS, the long-term relationship:

$$
Q=9.41 * 10^{-13}(\text { CRINT })+9.60 * 10^{-14}(\text { RESINT })+1,60+\varepsilon
$$

We Deduced from the estimate of the relationship (12), the series of residues, recall that:

- If the residues are non-stationary, the estimated relationship of long-term (12) is a spurious regression.

- If the residuals are stationary, the estimated relationship of long-term (12) is a cointegraton relationship.

To test the stationarity of residue, we will use the critical values tabulated by Mackinnon(1996) in applying the ADF test.

The results from applying the ADF test on residuals of the relationship between real exchange rate, domestic credit, international reserve given in appendix.

It is found that the estimated ADF statistic (-2.07) is less than the tabular value of Mackinnon at the 5\% (-1.95), 
this allows us to reject the hypothesis of nonstationarity of residue, where the residuals from the relationship between real exchange rate, domestic credit, international reserve are stationary. Therefore, the variables real exchange rate, domestic credit, international reserve are cointegrated. It is then possible to estimate the error correction model.

\subsection{Estimation of ECM}

After we examined the stationarity of the series and cointegration among the variables, we turn to the estimation stage of the model coefficients, but prior to this step, we must verify that the single cointegration relationship is an equation of real exchange rate and thus the other variables are weakly exogenous. For this purpose, we performed a simple test for exogeneity from the estimated VECM model using the Johansen method. This test is carried out through adjustment coefficient associated with the cointegration vectors.

From Table of VECM (Table A4 In appendix), we find that the adjustment parameters associated with the vector cointegration (speed adjustment) are not significant except for are not significant except for the first equation. The weak exogeneity test, we cannot therefore say that the equation (13) above is an equation written in real exchange rate.

After the test of weak exogeneity, we address the step of estimating the parameters of the equation of real exchange rate, according to Engle-Granger (1987) ; the simple method of estimating the long-term relationship between real exchange rate, and the variables domestic credit, the international reserves is to apply the method of ordinary least squares (OLS) regression to the following:

$$
Q_{t}=\alpha_{0}+\alpha_{3}\left(\operatorname{RESINT}_{t}\right)+\alpha_{4}\left(\operatorname{CRINT}_{t}\right)+\varepsilon_{t}
$$

With $\alpha_{0}, \alpha_{3}, \alpha_{4}$ represent the long-term coefficients.

The estimated parameters of equation (14) by OLS are biased and super convergent because the variables are cointegrated (Davidson \& Mackinnon, 1993). To improve estimates, we apply the correction of Stock and Watson (1988); equation (14) becomes:

$$
\begin{aligned}
& \mathrm{Q}_{\mathrm{t}}=\alpha_{0}+\alpha_{3}\left(\operatorname{RESINT}_{t}\right)+\alpha_{4}\left(\operatorname{CRINT}_{t}\right)+ \\
& \sum_{i=-p}^{p} \Delta\left(\operatorname{RESINT}_{\mathrm{t}-\mathrm{i}}\right)+\sum_{i=-p}^{p} \Delta\left(\operatorname{CRINT}_{t-i}\right)+\varepsilon_{t}
\end{aligned}
$$

We estimate the coefficients of the long-term relationship of the equation of real exchange rate as follows:

$$
\begin{aligned}
& \log \left(Q_{t}\right)=1,48+3,03 * 10^{-13}\left(\operatorname{RESINT}_{t}\right)+9,57 * 10^{-13}\left(\operatorname{CRINT}_{t}\right)+ \\
& 4,38 * 10^{-13} \Delta\left(\operatorname{RESINT}_{t}\right)(+1)-9,30 * 10^{-14} \Delta\left(\operatorname{RESINT}_{t}\right)-8,28 * 10^{-13}\left(\operatorname{RESINT}_{t}\right)(-1)+ \\
& 1,20 * 10^{-12} \Delta\left(\operatorname{CRINT}_{t}\right)(-1)+5,99 * 10^{-13} \Delta\left(\operatorname{CRINT}_{t}\right)+3,18 * 10^{-12}\left(\operatorname{CRINT}_{t}\right)(+1)+\varepsilon_{t}
\end{aligned}
$$

From Table A2 in appendix and according to the test of student; we find that all the coefficients of the differential equation (16) are not significant in level except for the present domestic credit.

The study of the relationship of short-term through ECM, allows us to analyze, in one hand, the speed of convergence of real exchange rate towards its equilibrium level of long term and, in other hand, the contribution he contribution of the fundamentals to the short-term dynamics. This brings us to test the significance of the equation parameters following short-term.

$$
\Delta \mathrm{Q}_{\mathrm{t}}=\phi z_{t-1}+\sum_{i=0}^{p} \mathrm{a}_{i} \Delta\left(\operatorname{RESINT}_{\mathrm{t}-\mathrm{i}}\right)+\sum_{\mathrm{i}=0}^{\mathrm{p}} \Delta\left(C R I N T_{t-i}\right)+\varepsilon_{t}
$$

With

$$
Z_{t-1}=\left(\mathrm{Q}_{\mathrm{t}-1}\right)-\left(\text { 牋. } .11^{*} 10^{-13}(C R I N T)+9.60 * 10^{-14}(\text { RESINT })+1,60+\varepsilon\right)
$$

With $Z_{t-1}$ is the residual of the cointegration relationship, and the error correction term (the adjustment term).

Model the real exchange rate based on residues from the previous period, the real exchange of a lag period, the intternational reserve and this lag for a period of domestic credit.

$$
\Delta Q_{t}=0,01-0,05 e_{t-1}+0,14 \Delta Q_{t-1}-1,57 * 10^{-14} \Delta\left(\operatorname{RESINT}_{t}\right)+4,58 * 10^{-13} \Delta\left(\operatorname{CRINT}_{t}\right)+\varepsilon_{t}
$$

The ECM of the equation of our model by the approach of Granger: 
We find that the coefficient associated with the restoring force is negative $(0.05)$ and significantly different from zero at $5 \%$ (the Student's t exceeds the tabulated value). There is therefore a mechanism for error correction. This mechanism indicates the convergence of trajectories of the series of real exchange rate towards long-term target. Thus, the impact on public spending of Morocco is correct to 5\% by effect of feedback.

The calculation of the duration of convergence can be achieved by the following formula:

$$
(1-\delta)=(1-|\varphi|)^{\mathrm{T}}
$$

With T, $\varphi$ and $\delta$ are respectively the number of years, the error correction coefficient and the percentage of shock. We used the inverse of the coefficient of restoring force to calculate the convergence time and we concluded that:

Shock observed during a given year is completely eliminated within twenty years.

We have found by the table of the ECM Granger approach (Appendix Table A3) that all coefficients of variables that explain the real exchange rate are not significant except domestic credit, this allows us to say that there is no relationship of short term between real exchange rate and the international reserve and domestic credit .

The method of Johansen (Appendix Table A4), shows that there is not a short-run relationship between real exchange rate and the explanatory variables of our model. We interpret our long-term equation obtained by the OLS:

$$
Q=9.41 * 10^{-13}(\text { CRINT })+9.60 * 10^{-14}(\text { RESINT })+1,60+\varepsilon
$$

We see the Table A1 in appendix; that all the coefficients of the equation are significant at $5 \%$, and the signs of the coefficients obtained are consistent with economic theory:

- The variable international reserve has a positive sign (the expected sign is positive) that allowed us to conclude that an increase in international reserve unit will result in an appreciation of the exchange rate of $9.6^{*} 10^{-12} \%$.

- The domestic credit has a positive influence on real exchange rate (the expected sign is negative). That allowed us to conclude that an increase in international reserve unit will result in an appreciation of the exchange rate of $9.41 * 10^{-10} \%$. This result contradict in the economy theory.

To implement the robustness tests on residuals, stability coefficients, we taken the following steps:

1- Using the Chow test for testing the stability of the coefficients (equalities between the coefficients). This test can be practiced only after determining the sub-periods.

To this end, we'll take two sub-periods:

First Period: 1980-1997, which 17 observations.

Second Period: 1997-2010, which 13 observations.

We recall that this test is based on the following statistic:

$$
\text { Chow }=\frac{R S S-R S S_{1}}{R S S_{1}} \frac{T_{1}+T_{2}-2 K}{2 K} \rightarrow F\left(K, \mathrm{~T}_{1}+T_{2}-2 K\right)
$$

RSS is the sum of squared residuals for all observations (30 observations), RSS is the sum of squared residuals for the first sub-period and $K$ : the number of variables.

Under $\mathrm{H}_{0}$ : equal coefficients against $\mathrm{H}_{1}$ : instability of the coefficients,

The application of this test gives us the following result:

$$
\text { Chow }^{\mathrm{c}}=66,86>F^{t}(2,26)=19.46
$$

According to the Chow test, we can conclude that the coefficients are unstable.

2- The residues of our empirical model meet four conditions: normality, stationarity, homoscedasticity and independence between the residuals.

The residues are actually distributed as a normal distribution, the Jarque-Bera test accepts the null hypothesis of normality JB $=0,56 \prec \chi_{0,05}^{2}(2)=5,99$.

The ADF test on residuals confirms the stationarity of the residuals using the table as critical values of Engle and Yoo (1987) ( $\mathrm{ADF}=-3.12$ estimated is less than the tabulated value which is equal to $-2,67)$. The White test (1980) accepts the null hypothesis and the homoscedasticity rejects the DW $=\breve{d}=0,64 ; \overrightarrow{\mathrm{d}} \prec \mathrm{d}_{\mathrm{L}}$ alternative 
hypothesis of hétéroscédasticité. The Durbin-Watson (DW) confirms the dependence of the errors.

3- To confirm that this relationship is generally stable, several tests can be used: tests of recursive residuals, CUSUM and CUSUM squares. This last test we will apply.

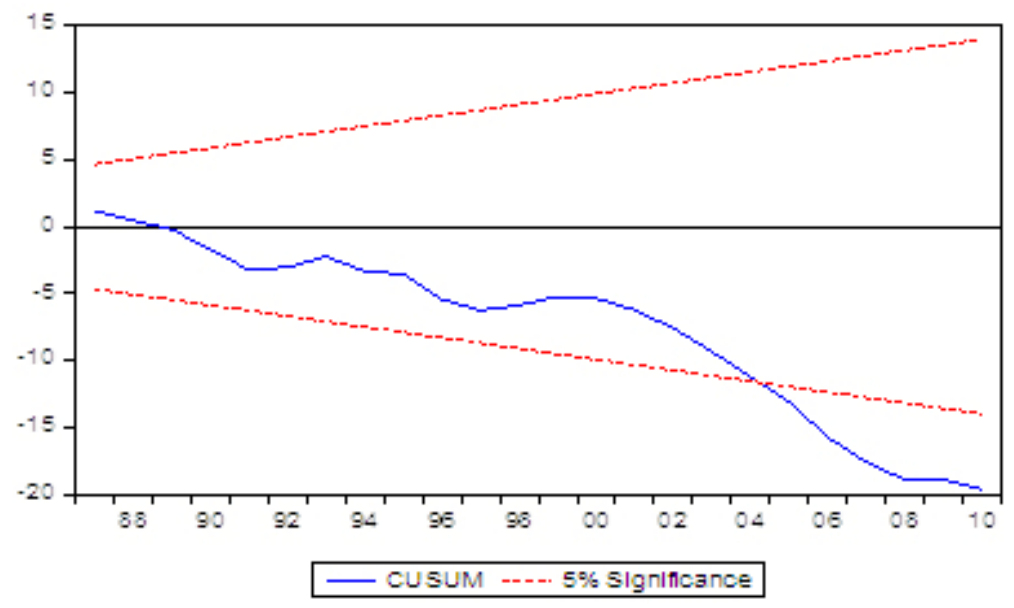

Figure 2. CUSUM test applied to the model coefficients

We observe in Figure 2 that the CUSUM leaves the interior corridor from 2004. This test allows us to say that the relationship is unstable.

4- The explanatory power in our model is $35 \%$, this allows us to say that the international reserve, the domestic credit strongly explain real exchange rate during the study period.

According to the statistical study we have treated, we can conclude that our model is generally satisfactory.

\section{Conclusion}

This paper presents the empirical application of the model of the monetary approach to the balance of payment using the method of co-integration and the ECM model. The results of our study are summarized:

- The variable international reserve has a positive sign (the expected sign is positive) that allowed us to conclude that an increase in international reserve unit will result in an appreciation of the exchange rate of $9.60 * 10^{-12} \%$.

- The domestic credit has a positive influence on real exchange rate (the expected sign is négatif). That allowed us to conclude that an increase in international reserve unit will result in an appreciation of the exchange rate of $9.41 * 10^{-10} \%$. This result contradict in the economy theory.

\section{References}

Allahoum, A. (2003). Essai d'Analyse des Déterminants du Taux de change: le cas du Dinar Algérien. ENSSEA.

Baffes, J., Elbadawi, I., \& O'connel, S. (1999). Single-Equation Estimation of the Equilibrium Real Exchange Rate. New York: Oxford University Press. http://dx.doi.org/10.1596/1813-9450-1800

Balassa, B. (1964). The Purchasing Power of Parity Doctrine: A Reappraisal. Journal of political Economy, 72 , 584-96. http://dx.doi.org/10.1086/258965

Bourguinat, H. (1997). Finance internationale (3rd ed.). Paris: PUF.

Bresson, G., \& Pirotte, A. (1995). Econométrie des séries temporelles. Paris: PUF.

Davidson, R., \& Mckinnon, J. (1993). Estimation and Inference in Econometrics. Oxford University Press.

Dickey, D, D., \& Fuller, W. (1981). likelihood ratio statistics for autoregressive time series with a unit root. Econometrica, 49. http://dx.doi.org/10.2307/1912517

Dornbusch, R. (s.d.). Expectations and exchange rate dynamics. Journal of political Economy, 84(6), 1976. http://dx.doi.org/10.1086/260506

Dornbush, R. (1973). Currency depreciation, horarding and relative prices. Journal of political Economy, 81, 893-915. http://dx.doi.org/10.1086/260087 
Edwards, S. (1989). Real Exchange Rates, Devaluation and Ajustement-Exchange Rate Policy in Developing Countries. Massachussets: MIT Press.

EkomiI, J. (2000). la dévaluation des francs CFA et l'approche monétaire de Ia balance des paiements (le cas du Gabon). Cahiers du SISERA.

Engle, R., \& Granger, C. (1987). co integration and error correction: Representation, estimation and testing. Econometrica, 55. http://dx.doi.org/10.2307/1913236

Engle, R., \& Yoo, S. (1987). Forecasting and Testing in Cointegrated Systems error. Journal of econometrics. http://dx.doi.org/10.1016/0304-4076(87)90085-6

Greffe, X. (1991). Politique économique. Paris: 2è edition Economica.

Hellier, J. (1994). Macroeconomic. Paris: PUF.

Johansen, S. (1988). Estimation and Hypothesis Testing of Cointegration Vectors in Gaussian Vector Autoregressive Models. Econometrica.

Johansen, S. (1991). Statistical Analysis of Cointegration Vectors. Journal of Economic Dynamics and control.

Johansen, S., \& Juselius, K. (1990). Maximum Likelihood Estimation and Inferences on cointegration with Application to the Demand for Money. Oxford: Oxford Bulletin of Economics and Statistics.

Johnson, H. (1975). The Monetary approach of payments theory: a diagrammatic analysis. Manchester School. http://dx.doi.org/10.1111/j.1467-9957.1975.tb01225.x

Johnson, H. (1977). The Monetary approach to the balance of payments, a non-technical guid. Journal of International Economics, 7(3), 251-268. http://dx.doi.org/10.1016/0022-1996(77)90039-3

Johnson, H., \& Frenkel, J. (1976). The Monetary approach to the balance of payments. London: Allen and Unwin.

Mohamed, K. (2003). Analyse de l'évolution du taux de change du dinar en rapport avec l'ajustement structurel de l'économie algérienne. Thèse de doctorat.

Mundell, R. A. (1960). The Monetary dynamics of international adjustment under fixed and floating exchange rate. Quaterly Journal of Economics, 74, 227-257. http://dx.doi.org/10.2307/1884252

Mussa, M. L. (1974). A monetary Approach to Balance payments Analysis. Journal of money, credit and Banking, 6, 333-351. http://dx.doi.org/10.2307/1991173

Neme, C. (1991). Economic internationale. Paris: Litec Economic.

Polack, J. (1958). Monetary Analysis of Income Formation and payments Problems. IMF Staff Papers, VI.

Polack, J., \& Argy, Y. (1971). Credit Policy and Balance of Payment. IMF Staff Papers.

Sandrine, L., \& Valérie, M. (2002). Econométrie des séries temporelles macroéconomiques et financière. Economica.

Stock, J., \& Watson, M. (1988). Testing for Common Trends. Journal of the American Statistical Association. http://dx.doi.org/10.1080/01621459.1988.10478707

Taline, K. (2005). The Equilibrium Real Exchange Rate in a commodity Exporting Country: Algeria's Experience. IMF.

White, H. (1980). A Heteroskedasticity-Consistant Covariance Estimator and a Direct Test for Heteroskedasticity. Econometrica. http://dx.doi.org/10.2307/1912934 


\section{Appendix}

Table A1. TCR estimation with OLS

Dependent Variable: TCR

Method: Least Squares

Date: 05/01/12 Time: 15:59

Sample: 19802010

Included observations: 31

\begin{tabular}{lllll}
\hline Variable & Coefficient & Std. Error & t-Statistic & Prob. \\
\hline C & 1.606778 & 0.108351 & 14.82932 & 0.0000 \\
RE & $9.60 \mathrm{E}-14$ & $2.29 \mathrm{E}-14$ & 4.191555 & 0.0003 \\
CI & $9.41 \mathrm{E}-13$ & $1.09 \mathrm{E}-13$ & 8.597891 & 0.0000 \\
\hline R-squared & 0.731568 & Mean dependent var & 2.261682 \\
Adjusted R-squared & 0.712394 & S.D. dependent var & \\
S.E. of regression & 0.343855 & Akaike info criterion & 0.641175 \\
Sum squared resid & 3.310618 & Schwarz criterion & 0.794573 \\
Log likelihood & -9.315883 & Hannan-Quinn criter. & 0.933346 \\
F-statistic & 38.15472 & Durbin-Watson stat & \\
Prob(F-statistic) & 0.000000 & & 0.487191 \\
\hline
\end{tabular}

Table A2. TCR estimation with Granger method

\begin{tabular}{|c|c|c|c|c|}
\hline \multicolumn{5}{|c|}{ Dependent Variable: TCR } \\
\hline \multicolumn{5}{|c|}{ Method: Least Squares } \\
\hline \multicolumn{5}{|c|}{ Date: $05 / 01 / 12$ Time: $13: 47$} \\
\hline \multicolumn{5}{|c|}{ Sample (adjusted): 19802009} \\
\hline \multicolumn{5}{|c|}{ Included observations: 30 after adjustments } \\
\hline Variable & Coefficient & Std. Error & t-Statistic & Prob. \\
\hline $\mathrm{C}$ & 1.482037 & 0.105611 & 14.03291 & 0.0000 \\
\hline RE & $3.03 \mathrm{E}-13$ & $2.27 \mathrm{E}-13$ & 1.335566 & 0.1960 \\
\hline CI & $9.57 \mathrm{E}-13$ & $1.51 \mathrm{E}-13$ & 6.325302 & 0.0000 \\
\hline $\mathrm{D}(\mathrm{RE}(1))$ & $4.38 \mathrm{E}-13$ & $2.81 \mathrm{E}-13$ & 1.556851 & 0.1344 \\
\hline $\mathrm{D}(\mathrm{RE})$ & $-9.30 \mathrm{E}-14$ & 3.37E-13 & -0.275949 & 0.7853 \\
\hline $\mathrm{D}(\mathrm{RE}(-1))$ & $-8.28 \mathrm{E}-13$ & $8.60 \mathrm{E}-13$ & -0.963049 & 0.3465 \\
\hline $\mathrm{D}(\mathrm{CI}(-1))$ & $1.20 \mathrm{E}-13$ & 4.36E-13 & 0.275446 & 0.7857 \\
\hline $\mathrm{D}(\mathrm{CI})$ & $5.99 \mathrm{E}-13$ & $5.12 \mathrm{E}-13$ & 1.168964 & 0.2555 \\
\hline $\mathrm{D}(\mathrm{CI}(1))$ & $1.18 \mathrm{E}-12$ & $3.98 \mathrm{E}-13$ & 2.967368 & 0.0073 \\
\hline S.E. of regression & 0.308067 & \multicolumn{2}{|c|}{ Akaike info criterion } & 0.726328 \\
\hline Sum squared resid & 1.993014 & \multicolumn{2}{|c|}{ Schwarz criterion } & 1.146687 \\
\hline Log likelihood & -1.894915 & \multicolumn{2}{|c|}{ Hannan-Quinn criter. } & 0.860804 \\
\hline Durbin-Watson stat & 0.711874 & & & \\
\hline
\end{tabular}

Table A3. ECM estimation with Granger method

\begin{tabular}{|c|c|c|c|c|}
\hline \multicolumn{5}{|c|}{ Dependent Variable: D(TCR) } \\
\hline \multicolumn{5}{|c|}{ Method: Least Squares } \\
\hline \multicolumn{5}{|c|}{ Date: 05/03/12 Time: $18: 54$} \\
\hline \multicolumn{5}{|c|}{ Sample(adjusted): 19772010} \\
\hline \multicolumn{5}{|c|}{ Included observations: 34 after adjusting endpoints } \\
\hline Variable & Coefficient & Std. Error & $\mathrm{t}$-Statistic & Prob. \\
\hline $\mathrm{C}$ & 0.019400 & 0.046658 & 0.415794 & 0.6806 \\
\hline $\mathrm{KK}(-1)$ & -0.053090 & 0.151476 & -0.350488 & 0.7285 \\
\hline $\mathrm{D}(\mathrm{TCR}(-1))$ & -0.148330 & 0.182914 & -0.810928 & 0.4240 \\
\hline $\mathrm{D}(\mathrm{RE})$ & $-1.57 \mathrm{E}-14$ & $9.86 \mathrm{E}-14$ & -0.159727 & 0.8742 \\
\hline$\underline{\mathrm{D}(\mathrm{CI})}$ & $4.85 \mathrm{E}-13$ & $2.26 \mathrm{E}-13$ & 2.142662 & 0.0407 \\
\hline R-squared & 0.351620 & \multicolumn{2}{|c|}{ Mean dependent var } & -0.000528 \\
\hline Adjusted R-squared & 0.262188 & \multicolumn{2}{|c|}{ S.D. dependent var } & 0.241460 \\
\hline S.E. of regression & 0.207404 & \multicolumn{2}{|c|}{ Akaike info criterion } & -0.173239 \\
\hline Sum squared resid & 1.247482 & \multicolumn{2}{|c|}{ Schwarz criterion } & 0.051226 \\
\hline Log likelihood & 7.945061 & \multicolumn{2}{|c|}{ F-statistic } & 3.931709 \\
\hline Durbin-Watson stat & 1.803594 & \multicolumn{2}{|c|}{ Prob(F-statistic) } & 0.011396 \\
\hline
\end{tabular}


Table A4. ECM estimation with Johansen method

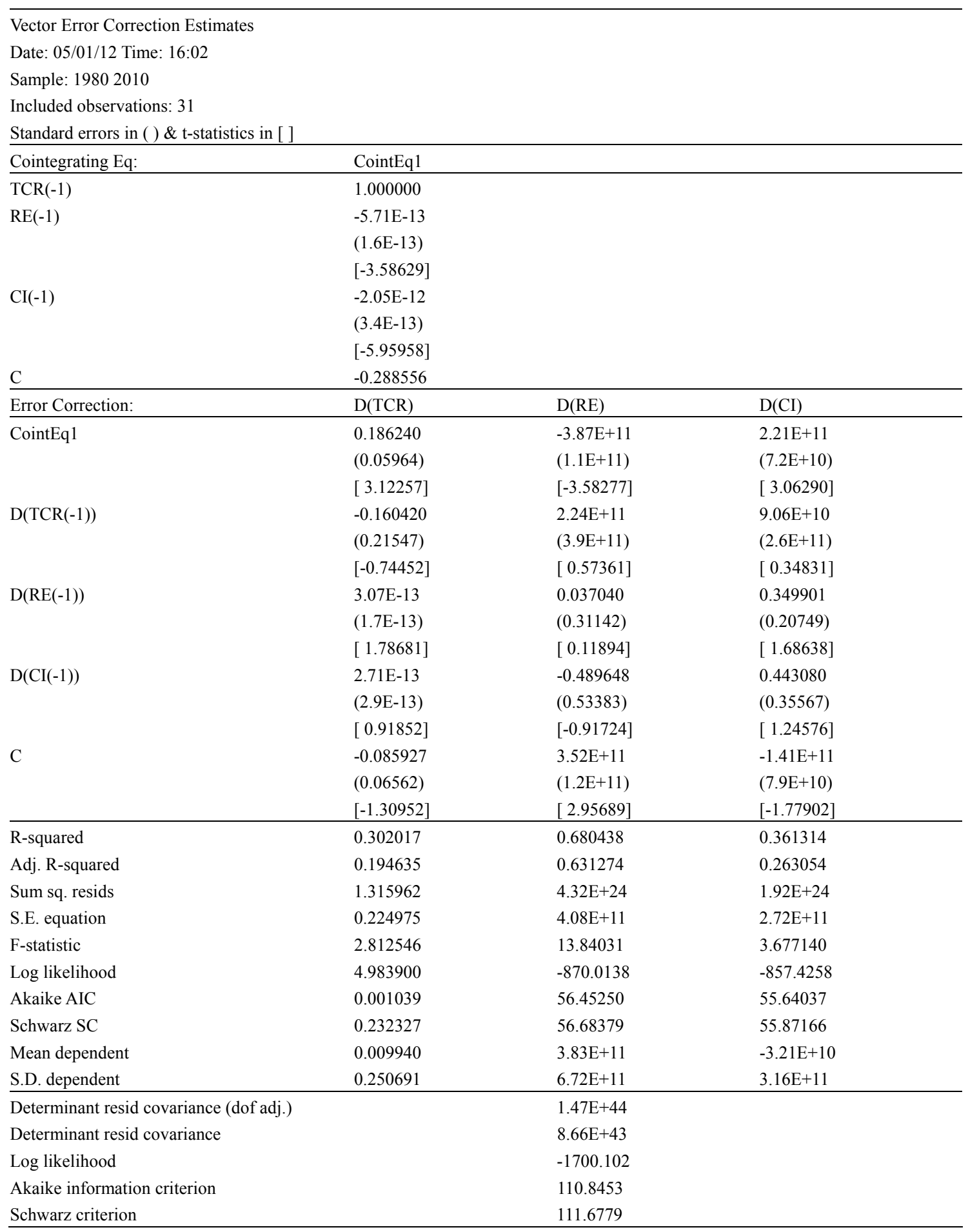

